\title{
Penanggulangan Perdagangan Manusia dan Pemenuhan Hak Korban di Desa Sukaraja
}

\author{
Fransiska Novita Eleanora1, Anggraeny Haryani Putri ${ }^{2}$ \\ 1,2Universitas Bhayangkara Jakarta Raya, vita_eleanor@yahoo.com
}

\begin{abstract}
Abstrak
Perdagangan manusia semakin marak terjadi dimana-mana, dimana penyebab utamanya adalah kemiskinan, lapangan kerja yang sempit dan banyaknya pengangguran, dan akibatnya menghalalkan segala cara, ketidakpahaman masyarakat terhadap perdagangan manusia mengakibatkan dirinya menjadi korban, yang mengalami penderitaan fisik, psikis, bahkan trauma yang berkepanjangan, dan butuh waktu yang lama untuk melakukan pemulihan dan rehabilitasi. Hal ini diatur dalam Undang-Undang No. 21 Tahun 2007 Tentang Tindak Pidana Pemberantasan Perdagangan Orang (TPPPO), dengan ancaman pidana penjara dan sanksi yang berat, kepada siapa yang terbukti melakukan tindak pidana perdagangan manusia berupa penjualan, penculikan, bujuk rayu, kebohongan, penculikan, penipuan yang mengakibatkan tereksploitasi. Hak-hak korban mengenai kompensasi, restitusi dan rehabilitasi merupakan tanggungjawab negara sebagai bentuk perlindungannya terhadap warganya. Tujuan dari dilakukannya kegiatan pengabdian ini agar masyarakat desa sukaraja kecamatan tambelang kabupaten bekasi dapat mengantisipasi diri untuk tidak menjadi korban perdagangan manusia, karena kejahatan akan selalu ada dimana saja, yang rentan untuk menjadi korban eksploitasi ekonomi dan seksual adalah anak dan perempuan, karena diangap lemah dan tidak mempunyai kekuatan untuk melakukan perlawanan. Sedangkan manfaatnya adalah, jikalau sudah terjadi korban, bagaimana prosedur yang harus dilakukan, untuk mendapatkan ganti rugi yang layak, dan bagaimana juga jika pelaku berasal dari keluarga yang tidak mampu, apakah ganti rugi dapat diberikan kepada korban, serta rehabilitasi yaitu tindakan pemulihan korban, dimana rehabilitasi medis dengan pemberian obat-obatan dan rehabilitasi psikososial dengan cara mengembalikan kepada keluarganya, dan masyarakat. Masyarakat dan keluarga mau menerimanya kembali seperti sedia kala.
\end{abstract}

Kata kunci: Perdagangan, Manusia, Hak, Tindak Pidana

\section{Abstract}

Human trafficking is becoming increasingly widespread, where the main causes are poverty, narrow employment and unemployment, and consequently justifies any means, people's lack of human trafficking leads to victimization, suffering physical, psychological, and even prolonged psychiatric disorder, and it took a long time for recovery and rehabilitation. This is regulated in Law no. 21 Year 2007 on the Crime of Combating Trafficking in Persons (TPPPO), with the threat of imprisonment and severe penalties, to those proven to commit human trafficking in the form of sales, kidnappings, seductions, lies, kidnappings, fraud which resulted in exploitation. The rights of victims of compensation, restitution and rehabilitation are the responsibility of the state as a form of protection against its citizens. The 
purpose of this community service is to ensure that the villagers in the sub-district on Bekasi district of Tambelang can anticipate themselves not to become victims of trafficking, because crime will always be anywhere, vulnerable to become victims of economic and sexual exploitation are children and women, because they are considered weak and have no power to resist. While the benefits are, if there is a victim, how the procedure should be done, to get a decent compensation, and how also if the perpetrator comes from poor families, whether the compensation can be given to the victim, and rehabilitation is the recovery of the victim, where medical rehabilitation with the provision of medicines and psychosocial rehabilitation by returning to his family, and the community. People and families want to take it back as usual.

Keywords: Trade, Human, Rights, Crime

\section{Pendahuluan}

Indonesia merupakan negara hukum dan dalam menerapkan aturan-aturan hukum, sangat diperlukan sanksi yang bersifat tegas dan memaksa bagi mereka yang dianggap melanggar aturan hukum. Aturan-aturan hukum yang ada harus senantiasa berkembang mengikuti perkembangan jaman, mengikuti perkembangan masyarakat yang selalu dinamis, seiring dengan adanya perkembangan atau perubahan dari waktu ke waktu, yang sesuai dengan kebutuhan masyarakat banyak. Tidak hanya hukum atau aturan yang berubah atau meningkat, kejahatan ataupun pelanggaran pun makin meningkat dan semakin marak terjadi, tidak pandang siapa pelakunya tua muda, kaya miskin, dewasa ataupun anak-anak, kepercayaan terhadap hukum sudah tidak ada lagi, kejahatan dan pelanggaran ini sudah banyak terjadi dihampir semua Negara, tingkat kriminalitas yang sangat tinggi, upaya pencegahan preventif dan represif sudah dilakukan semaksimal mungkin, tetapi tingkat kejahatan masih saja meningkat.

Salah satu kejahatan yang makin marak terjadi dan terus meningkat adalah perdagangan manusia, cara-cara dan modus operandi yang dilakukan sangat beragam dan berbeda-beda, (Mohammad Hatta,2012) tindak pidana perdagangan manusia termasuk kejahatan kemanusiaan yang sangat melanggar hak-hak kemanusiaan dari setiap individu, dan tanpa pandang bulu, korbannya kebanyakan dari perempuan dan anak yang sangat rentan dengan kekerasan, serta dijadikan eksploitasi baik ekonomi maupun seksual.

Undang-Undang Nomor 39 Tahun 1999 tentang Hak Asasi Manusia (HAM) mengisyaratkan bahwa hak asasi manusia adalah seperangkat hak yang dimiliki oleh setiap orang dan merupakan pemberian Tuhan Yang Maha Esa yang dibawa sejak lahir. Sudah jelas bahwa tindak pidana perdagangan manusia merupakan pelanggaran Hak Asasi Manusia (HAM) berat. Tindak Pidana Perdagangan Manusia tidak hanya dengan janji atau iming-iming manis untuk bekerja diluar negeri yang digunakan oleh pelaku untuk membujuk korbannya, tetapi banyak cara salah satunya dengan menggunakan media sosial seperti facebook, twitter yang digunakan oleh pelaku untuk menjual anak-anak baik secara lokal maupun Internasional. (Rita Pranawati, 2015)

Bahaya kejahatan human traficking dapat menimbulkan penyakit, ataupun stress, tidak hanya penyakit pada anak-anak pun sering mengalami pertumbuhan yang 
lambat, adanya ekspoitasi seksual yang mengakibatkan tertularnya virus HIV/AIDS, trauma yang berkepanjangan dan bisa menyebabkan kematian. Anak dan perempuan, sesuai dengan Undang-Undang No. 35 Tahun 2024 tentang Perubahan atas Undang-Undang No. 23 Tahun 2002 tentang Perlindungan Anak seringkali dijadikan korban eksploitasi, dikarenakan kemiskinan, susahnya mendapatkan pekerjaan, gaya hidup yang ingin kemewahan merupakan salah satu fenomena terjadinya tindak pidana perdagangan manusia.

Tujuan dari kegiatan pengabdian masyarakat ini adalah

a) Agar Masyarakat desa sukaraja mengetahui bahaya human traficking cara penanggulangan tindak pidana perdagangan manusia baik secara preventif maupun represif, serta sanksi yang mengaturnya

b) Penyuluhan hukum pemenuhan hak-hak korban, berupa restitusi, kompensasi, rehabilitasi dan jaminan untuk tidak terulang lagi

Manfaat dari Pengabdian Kepada masyarakat adalah suatu kegiatan yang dirumuskan oleh TIM Fakultas Hukum Universitas Bhayangkara Jakarta Raya, diharapkan agar :

a) Masyarakat desa sukaraja mempunyai kesadaran hukum dan tanggung jawab untuk mengimplematsikan didalam kehidupan keluarga, lingkungan dan masyarakat.

b) Memahami aturan-aturan dan sanksi yang berkaitan dengan Tindak Pidana Perdagangan Manusia dalam rangka mewujudkan penegakan hukum.

Dalam mengkaji suatu permasalahan, tidak terlepas dari teori-teori yang menjadi landasan, dalam memecahkan suatu masalah yang akan diteliti. Khususnya teori yang akan dikaji adalah teori sistem pemidanaan. Teori Sistem Pemidanaan, dalam pemberlakuannya secara umum ada (3) yaitu:

Teori Sistem Pemidanaan, dalam pemberlakuannya secara umum ada (3) yaitu:

(1) Teori Pembalasan

Pembalasan yang sesuai dengan perbuatannya, jika seseorang melakukan kejahatan/pelanggaran, atau lebih tepatnya tindak pidana, yang dapat mengakibatkan kerugian/kerusakan/cacat/kematian, maka patut mendapatkan pembalasan yang setimpal berupa penderitaan yang sama beratnya dengan akibat yang ditimbulkannya, dengan kata lain, akan ada ganjaran yang didapatkan.

(2) Teori Tujuan

Masyarakat perlu dilindungi untuk mencegah agar tidak terjadi kejahatan, sehingga teori ini lebih tepat dikatakan sebagai teori perlindungan masyarakat, dengan memberikan perlindungan kepada masyarakat, Negara menjadi makmur, adil, tenteram dan damai. Tidak ada satupun tindak pidana yang terjadi, semua hidup dalam kedamaian.

(3) Teori Gabungan

Merupakan gabungan/perpaduan dari teori pembalasan dan tujuan, artinya tetap meberikan hukuman yang setimpal dengan kesalahannya tetapi lebih diarahkan kepada pembinaan, khususnya kepada perbuatan, mental dan kejiwaan, pelaku diarahkan untuk lebih baik lagi, dalam teori gabungan ini 
sudah melekatkan pada sistem pemasyarakatan daripada sistem pemenjaraan.

(SR. Sianturi \& Mompang LP, 1996)

Dengan kajian teori diatas, kegiatan pengabdian masyarakat dilaksanakan selama 1 (hari) yaitu pada tanggal 14 Desember 2017, yang diikuti sekitar 36 peserta warga masyarakat laki-laki dan perempuan yang ada di Desa Sukaraja, Kecamatan Tambelang, Kabupaten Bekasi.

\section{Metode}

Sistem atau tindakan apa yang dilakukan didalam memecahkan suatu masalah, tahapan-tahapan serta langkah-langkah yang dilakukan, agar mendapatkan hasil yang maksimal serta mempunyai manfaat terhadap masyarakat luas.

(1)Analisa Situasi Masyarakat

Masyarakat perlu diberikan pemahaman, pengetahuan tentang dampak dan penanggulangan tindak pidana perdagangan manusia. Karena kejahatan ini semakin meningkat, diharapkan agar masyarakat desa sukaraja kecamatan tambelang kabupaten Bekasi, mempunyai kesiapan dalam menghadapi kejahatan yang terjadi dilingkungan tempat tinggalnya.

(2)Identifikasi Masalah

Modus Operandi, Cara dan Proses terjadinya tindak pidana perdagangan manusia, Sanksi yang mengaturnya serta hak-hak korban perdagangan manusia, pemahaman ini diberikan agar masyarakat mengetahui bahwa hukum memberikan perlindungan kepada korban.

(3)Menentukan Tujuan Kerja

Kegiatan ini diharapkan sudah ada perubahan sebelum dan sesudah kegiatan tersebut terlaksana, hasilnya dapat dilihat pada pre test dan post test, pada pre test tingkat pengetahuan dan pemahaman masyarakat relatif minim belum pernah mendengar "perdagangan manusia", namun setelah diberikan post test pemahaman masyarakat lebih luas dan mengerti tentang dampak, sanksi, penanggulangan dan hak-hak korban.

(4)Rencana Pemecahan Masalah

Menekankan dan menguatkan Pemahaman Masyarakat tentang Penegakan Hukum, Sosialisasi akan Undang-Undang Perdagangan Manusia beserta sanksi yang mengaturnya serta menghukum pelaku dengan seberat-beratnya.

(5)Pendekatan Sosial

Adanya sesi tanya jawab yang diajukan oleh masyarakat desa sukaraja kepada narasumber, masyarakat sangat antusias dalam memberikan pertanyaan, dan disampaikan juga, jika ada masyarakat yang hendak bertanya atau menemukan sesuatu fenomena, bisa langsung datang ke FH Universitas Bhayangkara Jakarta Raya, Ke bagian Lembaga Konsultasi Bantuan Hukum (LKBH), untuk mendapatkan bantuan hukum.

(6)Pelaksanaan Kegiatan 
Beberapa tahapan dalam Pelaksanaan Kegiatan :

(i) Bagaimana Kegiatan itu dilakukan

Kegiatan Pengabdian ini dilakukan dengan Sosialisasi/Penyuluhan, dari pihak desa sukaraja, kata sambutan disampaikan oleh Lurah atau yang mewakili, sedangkan dari pihak Universitas adalah Ketua LPPMP, Ibu Dr. Irma Setyawati, SE., MM, dilanjutkan dengan Presentasi oleh 2 (dua) orang Narasumber, yaitu Fransiska Novita Eleanora, SH., M.Hum dan Anggraeny Haryani Putri, SH., MH, tentang tindak pidana perdagangan manusia serta hak-hak korban perdagangan manusia. Setelah presentasi dibuka dengan sesi tanya jawab.

(ii) Penetapan Waktu Pelaksanaan

Kegiata Pengabdian Masyarakat ini dilaksanakan Pada Hari Kamis, tanggal 14 Desember 2017, Jam 09.00 - 12.00 wib

(iii) Penetapan Tempat Pelaksanaan Kegiatan

Kegiatan Pengabdian dilaksanakan di Aula Desa Sukaraja Kecamatan Tambelang Kabupaten Bekasi

(iv) Penetapan orang-orang yang terlibat dalam kegiatan pengabdian

Dari Pihak Fakultas Hukum Universitas Bhayangkara Jakarta Raya mengikutsertakan beberapa mahasiswa, yang bertugas sebagai Moderator, Notulen, serta mengikuti sesi kegaiatan pengabdian masyarakat. Pihak dari Desa Sukaraja melibatkan ibu-ibu PKK dan pihak dari sekretaris desa. Warga masyarakat merasa senang dan bangga dengan kegiatan pengabdian ini, serta meminta dan menghimbau agar terus dipererat hubungan ini, dan selalu memberikan sosialisasi dengan tema yang berbeda, sehingga bisa dikatakan nantinya desa sukaraja bisa dijadikan desa binaan.

(7)Evaluasi Kegiatan dan Hasil

Kegiatan pengabdian yang sudah dilakukan, mencakup warga desa sukaraja, yaitu ibu-ibu PKK, dan ada beberapa perwakilan dari pihak sekretaris desa, hasil yang dicapai cukup dimuaskan, bisa dikatakan $85 \%$ dari warga yang mengikuti pengabdian sudah paham dan mengerti tentang materi yang dipaparkan, dan dapat dilihat dari post test yang telah dibagikan, menunjukkan sudah ada perubahan sebelum ada kegiatan kepada pengabdian kepada masyarakat. Namun, bisa diperluas untuk kedepannya dengan melibatkan karang taruna, ibuibu penggajian, pengurus-pengurus desa. Karena Desa Sukaraja rencananya akan menjadi Desa Binaan, tentunya harapan kedepan desa tersebut dapat mewujudkan pola pendidikan dan pelayanan hukum yang berkesinambungan menuju masyarakat yang adil dan sejahtera, peran perguruan tinggi sebagai fasilitator dan mediator dalam memberikan arahan agar dapat terwujud.

\section{Hasil Dan Pembahasan}

Pengabdian kepada masyarakat lebih menitikberatkan kemampuan dari warga masyarakat desa sukaraja dalam menganalisis aturan suatu undang-undang, yang akan direalisasikan kasus atau kejahatan perdagangan manusia. 
Sebagian besar pekerjaan dari masyarakat desa sukaraja adalah bertani, pemahaman mereka tentang kejahatan perdagangan manusia masih simpang siur, apalagi jika menyangkut hak-hak korban.

Tabel 1. Perbandingan Pra Pengabdian dan Pasca Pengabdian Penaggulangan Tindak Pidana Perdagangan Manusia

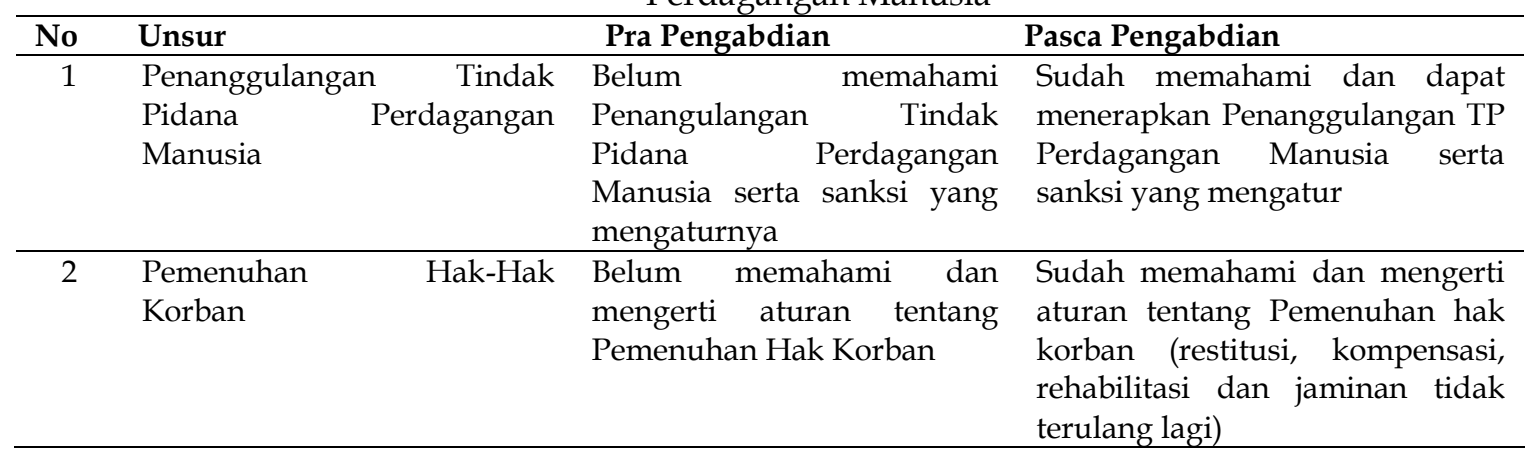

\section{Hasil Pengamatan Sebelum Pra Pengabdian}

Dari tabel diatas, bahwa sebelum pra pengabdian belum memahami bagaimana penanggulangan tindak pidana perdagangan manusia, yang mereka ketahui adalah suatu kejahatan, belum ada penyuluhan secara spesifik tentang kejahatan tersebut, dan bisa dikatakan hanya isu-isu aktual saja yang didengar dari siaran televisi, radio atau surat kabar.

Hasil pengamatan I, juga didapatkan bahwa ada masyarakat desa sukaraja yang belum pernah menjadi korban human trafficking, tetapi perlu ditingkatkan kewaspadaan diri, karena kejahatan bisa datang kapan dan dimana saja. Dari hasil pretest ditemukan hasil, 50\% responden menjawab, bahwa penyebab dari human trafficking (perdagangan manusia), dikarenakan :

a) Kemiskinan

b) Kurangnya Lapangan Kerja

c) Tingkat pendidikan yang sangat rendah

d) Hukuman terhadap pelaku yang sangat ringan dan

e) Kurangnya kepedulian aparat pemerintah terhadap kejahatan tersebut. (Rika Saraswati, 2015)

Sedangkan cara penanggulangan dan banyaknya aturan -aturan yang ada, serta sanksi/hukuman yang tegas, tidak semua warga mengetahuinya, apalagi bunyi pasal-pasal serta hukuman yang akan dijatuhkan kepada pelaku, kejahatan ini terus berkembang, bahkan dengan kecanggihan teknologi sudah bisa dilakukan di Media Sosial seperti melalui facebook, twitter dll.

Hasil Pengamatan II, masyarakat desa sukaraja juga tdak memahami tentang ganti rugi, prosedur yang akan diajukan, serta tidak mengertahui bahwa hal tersebut adalah kewajiban Negara untuk memberikan ganti rugi kepada warganya, hak korban didampingi kuasa hukum, serta kewajiban aparat penegak hukum bertugas mengarahkan agar korban perdagangan manusia mendapatkan hak-haknya yang berkeadilan dan berkepastian hukum. (Rizky Ariestandi, 2013). 


\section{Hasil Pengamatan Setelah Pasca Pengabdian}

Hasil Pengamatan I, setelah dilakukan penyuluhan/sosialisasi, dan dibuka dengan sesi tanya jawab, akhirnya warga masyarakat desa sukaraja, secara perlahan, sudah mulali memahami apa itu perdagangan manusia, sebab terjadinya perdagangan manusia, faktor penyebab terjadinya perdagangan manusia, serta cara-cara penanggulangannya, disamping ada beberapa pertanyaan dari masyarakat sangat antusias dalam mengemukakan persoalan hidupnya, terkait perdagangan manusia, tetapi yang palin penting dari semua itu, perlunya ada menumbuhkan kesadaran diri dalam setiap insan, dan kesadaran hukum itu yang paling utama.

Hasil pengamatan II, bahwa sebagai warga masyarakat sudah memahami akan hakhak korban, seperti kompensasi, restitusi dan rehabilitasi, hak-hak ini diberikan karena merupakan bagian dari hak asasi manusia (ham), dan hak ini dibebankan kepada pelaku, bukan hanya warga masyarakat saja yang memahami, tetapi lurah, sekretaris desa berserta pengurus-pengurus desa lainnya, sudah memahami apa yang dimaksud dengan hak-hak korban.

\section{Pembahasan}

Berdasarkan paparan hasil pengamatan diatas, maka pembahasan dapat dikembangkan dalam bentuk :
a) Pendidikan Hukum
b) Pelayanan Masyarakat
c) Praktek

Penyuluhan tidak hanya memberikan materi, pemahaman sekedar mengetahui, tetapi harus didukung oleh kemandirian dari setiap responden, kalau dengan memberikan pendidikan hukum kepada masyarakat sedini mungkin, pencegahan untuk terhindar dari suatu kejahatan bisa terjadi. Pendidikan hukum juga bertujuan agar masyarakat tidak melakukan perbuatan-perbuatan tercela ataupun yang menyimpang dari agama dan negara. Jadi tidak hanya memberikan pemahaman pada saat pengabdian saja, tetapi harus dilatih terus-menerus, karana yang namanya pendidikan akan terus berjalan, tidak akan berhenti, yang penting ada niat dan kemauan yang besar untuk melaksanakan pendidikan hukum, karena minimya pendidikan hukum di Indonesia, menjadi pendorong banyaknya kejahatan dan pelanggaran yang terjadi, survei membuktikan tingkat kriminalitas semakin hari semakin tinggi untuk melakukan tindak pidana.

Ketentuan Kitab Undang-Undang Hukum Acara Pidana (KUHAP) Pasal 50-64 Undang-Undang No. 8 Tahun 1981 dijelaskan bahwa hak-hak tersangka/pelaku berhak mendapatkan bantuan hukum secara Cuma-Cuma atau gratis. Sedangkan korban menurut Peraturan Pemerintah No. 3 Tahun 2002 Tentang Kompensasi, Restitusi, Dan Rehabilitasi Terhadap Korban Pelanggaran HAM yang Berat. Intinya pelaku dan korban tetap mendapatkan bantuan hukum. Bentuk pelayanan masyarakat sebenarnya yang paling melekat yaitu peran perguruan tinggi memberikan pelayanannya, misalnya di Fakultas Hukum Universitas Bhayangkara Jakarta Raya, ada LKBH (Lembaga Konsultasi Bantuan Hukum).

Masyarakat sebagai pelaku bisa saja membutuhkan pendampingan dalam menghadapi kasus pidana ataupun perdata yang dihadapinya, disinilah dituntut 
pelayanan masyarakat untuk lebih percaya dalam penyelesaian masalah yang dihadapinya. Peran perguruan tinggi memberikan pelayanan dengan mendampinginya melalui kuasa hukumnya. Undang-Undang Nomor 16 Tahun 2011 tentang Bantuan Hukum, Pasal 2, bahwa orang atau kelompok orang miskin berhak untuk menerima bantuan hukum, untuk melindungi harkat, martabatnya sebagai manusia seutuhnya.

Pembahasan ke-3 adalah Praktek di dalam masyarakat, disini masyarakat diajarkan dalam memecahkan suatu kasus, kronologis peristiwanya bagaimana, atau membuat suatu "peradilan semu" jika masuk dalam program kekhususan pidana, sehingga masyarakat dapat mengetahui dan memahami tugas, fungsi dan peran dari setiap aparat penegak hukum (polisi, jaksa dan hakim). Tujuannya agar masyarakat tidak buta akan hukum, selain sudah memahami aturan-aturan hukum beserta sanksinya, perlu juga pemahaman tentang prosedur hukum yang benar.

Sedangkan dalam program kekhususan perdata, tentunya tidak beda jauh dengan pidana, yang bisa dipraktekkan dalam perdata, misalnya, pembuatan surat kontrak, surat perjanjian, klausul-klausul yang harus dicantumkan dalam pembuatannya, halhal seperti itu perlu diajarkan kepada masyarakat luas, kepada masyarakat terpencil. Jika praktek ini dilaksanakan, kemungkinan besar tingkat pengetahuan, lebih besar lagi, dan dapat menstrasfer ilmunya kepada teman-temannya atau keluarganya yang bertempat tinggal di desa lain. Sebenarnya kemandirian seperti inilah yang sangat sangat dibutuhkan, dan praktek serta kemandirian ini tidak terlepas dari peran perguruan tinggi dalam memajukan desa binaannya.

\section{Simpulan dan Rekomendasi}

Dari pembahasan diatas maka dapat ditarik kesimpulan dan saran, sebagai berikut :

Tindak Pidana Perdagangan manusia merupakan pelanggaran kejahatan hak asasi manusia berat, dimana dilakukan dengan banyak cara, salah satunya adalah dengan menggunakan media internet untuk melakukan perdagangan manusia yang memanfaatkan media online, segala cara dihalalkan untuk memenuhi kebutuhan hidup, tanpa pandang bulu. Pemenuhan hak-hak korban perdagangan manusia berupa restitusi, kompensasi, dan rehabilitasi merupakan kewajiban Negara, untuk memenuhi rsa keadilan dan kepastian hukum yang dibebankan kepada pelaku, dimana diprosedurnya dilaksanakan melalui pihak penyidik dan kejaksaan.

Pemahaman masyarakat desa sukaraja kecamatan tambelang kabupaten Bekasi terhadap bahaya perdagangan manusia, harus lebih ditingkatkan lagi, dengan berbagai bentuk tindak pidana yang lain, artinya penyuluhan/sosialisasi ini harus terus berlanjut, khususnya akan lebih mengarahkan pada pengetahuan akan pasalpasal ataupun sanksi dalam undang-undang, diperlukan adanya pendidikan hukum ditengah-tengah masyarakat.Penyuluhan ini harus tetap ditingkatkan dan selalu berkelanjutan, sehingga diperlukan adanya Desa Binaan, tujaunnya agar ilmu pengetahuan hukum yang diterima masyarakat dapat terus berkembang dan berguna bagi dirinya sendiri dan bagi masyarakat luas khususnya, dalam pengembangan ini sangat dibutuhkan sarana dan prasarana yang memadai, agar dapat berjalan dengan baik.Agar Kegiatan pengabdian dapat dirasakan manfaatnya bagi masyarakat luas, diperlukan adanya praktek berupa pendidika hukum dan 
pelayanan masyarakat, berbentuk kemandirian kepada warga masyarakat desa sukaraja kecamatan tambelang Kabupaten Bekasi, sehingga Kegiatan pengabdian ini akan terus berkelanjutan

\section{Daftar Pustaka}

SR Sianturi \& Mompang L. Panggabean, Hukum Penitensia Di Indonesia, Cetakan Pertama, Alumni Ahaem-Petehaem, Jakarta, 1996

Mohammad Hatta, Tindak Pidana Perdagangan Orang Dalam Teori Dan Praktek, Cetakan Pertama, Liberty, Yogyakarta, 2012

Rizky Ariestandi Irwansyah, Hukum, Hak Asasi Manusia, dan Demokrasi, Cetakan Pertama, Graha Ilmu, Yogyakarta, 2013

Rita Pranawati, Harapan dan Realita, 2 Tahun Implementasi Sistem Peradilan Pidana Anak (SPPA), Cetakan Pertama, KPAI, 2015

Rika Saraswati, Hukum Perlindungan Anak Di Indonesia, Cetakan kedua, Citra Aditya Bakti, Bandung, 2015

UU No. 8 Tahun 1981 tentang Kitab Undang-Undang Hukum Acara Pidana (KUHAP)

UU No. 39 Tahun 1999 tentang Hak Asasi Manusia (HAM)

UU No. 21 Tahun 2007 tentang Pemberantasan Tindak Pidana Perdagangan Orang (TPPO)

Undang-Undang Nomor 16 Tahun 2011 tentang Bantuan Hukum

UU No. 35 Tahun 2014 tentang Perubahan atas Undang-Undang No. 23 Tahun tentang Perlindungan Anak

Kompensasi, Restitusi, Dan Rehabilitasi Terhadap Korban Pelanggaran HAM yang Berat Peraturan Pemerintah No. 3 Tahun 2002 